\title{
WĘZŁOWE PROBLEMY WYKŁADNI PRZEPISÓW PRAWA KARNEGO MATERIALNEGO PRZY UWZGLĘDNIENIU DYREKTYWY WYKŁADNI PRZYJAZNEJ PRAWU UNIJNEMU
}

Przystąpienie Rzeczypospolitej Polskiej do Unii Europejskiej wpłynęło nie tylko na sferę polityczną, gospodarczą, społeczną, lecz także stało się momentem przełomowym $\mathrm{w}$ systemie prawa, zwłaszcza $\mathrm{w}$ jego podstawach aksjologicznych oraz w kwestii stosowania prawa. Zmiany nie ominęły interpretacji prawniczej - pojęcia, takie jak ,prowspólnotowa wykładnia prawa krajowego”, ,wykładnia przyjazna prawu europejskiemu”, „prounijna wykładnia prawa krajowego”, stanowią jej znamienne przykłady ${ }^{1}$. Fakt zaistnienia zmian w tej materii nie dziwi, ponieważ jedną z podstawowych metod zapewniania efektywności prawu unijnemu jest zasada prounijnej wykładni prawa. Jest ona elementem systemu zasad służących urzeczywistnieniu prawidłowego oraz jednolitego stosowania acquis communautaire we wszystkich państwach członkowskich Unii Europejskiej.

$\mathrm{Na}$ wstępie warto wskazać, że podstawę prawną dla obowiązku prowspólnotowej wykładni prawa krajowego stanowił art. 10 Traktatu o ustanowieniu Wspól-

Zob. P. Kardas, Rola i znaczenie wykładni prowspólnotowej w procesie dekodowania norm prawa karnego. Uwagi na marginesie uchwały SN z dnia 3 marca 2009 r. (I KZP 30/08), „Czasopismo Prawa Karnego i Nauk Penalnych" 2009, z. 2, s. 23-27; M. Rams, Znaczenie wykładni zgodnej dla interpretacji przepisów kodeksu postępowania karnego na przykładzie problematyki dostępu do akt sprawy w postępowaniu w przedmiocie tymczasowego aresztowania, e-Czasopismo Prawa Karnego i Nauk Penalnych 14/2013; G. Krzysztofiuk, Obowiązek prounijnej interpretacji prawa karnego, „Studia luridica” 2006, vol. XLVI, s. 209-222; M. Wąsek-Wiaderek, (w:) A. Grzelak, M. Królikowski, A. Sakowicz (red.), Europejskie prawo karne, Warszawa 2012, s. 281-290; A. Sakowicz, The principle of conforming interpretation of national law in the area of criminal law. General remarks, „Studies in Logic, Grammar and Rhetoric” 2012, vol. 31 (44), s. 83-97. K. Płeszka, „lus” i „lex” w prowspólnotowej wykładni prawa krajowego, (w:) Prawo, władza, społeczeństwo, polityka. Księga jubileuszowa Profesora Krzysztofa Pałeckiego, Kraków 2006, s. 102 i n.; w literaturze anglojęzycznej zob. S. Prechal: Directives in EC Law, Oxford 2005, s. 181; G. Betlem, The Doctrine of Consistent Interpretation-Managing Legal Uncertainty, „Oxford Journal of Legal Studies” 2002, vol. 22, nr 3, s. 397-418; S. Lefevre, Interpretative communications and the implementation of Community law at national level, „European Law Review” 2004, vol. 29, nr 6, s. 808-822; T. Koopmans, The Theory of Interpretation and the Court of Justice, (w:) D. O'Keeffe, A. Bavasso (eds), Judicial review in European Union Law - Liber Amicorum in Honour of Lord Slynn of Hadley, The Hague-London-Boston 2000, s. 45; M. Poiares Maduro, Interpreting European Law: Judicial Adjudication in the Context of Constitutional Pluralism, „European Journal of Legal Studies” 2007, vol. 1, s. 1 i n.; G. Itzcovich, The Interpretation of Community Law by the European Court of Justice, „German Law Journal” 2009, vol. 10, s. 537 i n; G. Conway, The Limits of Legal Reasoning and the European Court of Justice, Cambridge 2012, passim. 
noty Europejskiej (dalej: TWE). Potwierdził to Trybunał Sprawiedliwości w sprawie von Colson i Kamann przeciwko Nadrenii Północnej - Westfalii (sygn. akt C-14/83), stwierdzając, że obowiązek nałożony na państwa członkowskie w art. 10 TWE (tj. podjęcia wszelkich właściwych środków o charakterze ogólnym lub szczególnym w celu zapewnienia wykonania zobowiązań wynikających z Traktatu oraz z działań instytucji Wspólnoty) dotyczy również sądów krajowych, które stosując prawo krajowe, a w szczególności przepisy implementujące dyrektywę, powinny interpretować je w świetle postanowień i celu danej dyrektywy. W orzeczeniu tym Trybunał wprowadził pojęcie skuteczności pośredniej dyrektywy (indirect effect), które odnosi się do stosowania przepisów prawa krajowego wydanych w celu wykonania dyrektywy. Zgodnie z tą zasadą sądy powinny dokonywać interpretacji owych przepisów „w świetle brzmienia i celów” dyrektywy, która sama w sobie nie wywołuje skutku bezpośredniego. To rozwiązanie wywiedziono z obowiązku zapewnienia realizacji celu dyrektywy ciążącego na państwach członkowskich. Przyjęto bowiem, że skoro dyrektywa sama nie skutkuje bezpośrednio, to jej cele w zakresie stosowania prawa krajowego można osiągnąć właściwie tylko w taki sposób. Idąc dalej, Trybunał stwierdził nawet, że sądy krajowe powinny domniemywać zamiar pełnego wykonania zobowiązań płynących z dyrektywy i uchylać się od zastosowania przepisów krajowych dopiero po stwierdzeniu, że w żaden sposób nie dają się one pogodzić z dyrektywą ${ }^{2}$.

Obecnie obowiązek wykładni prawa krajowego zgodnie z prawem unijnym istnieje z mocy zasady lojalności (art. 4 ust. 3 TUE) oraz konieczności zapewnienia efektywności norm prawa unijnego zgodnie z celami przez nie wytyczonymi. Z przedmiotowej zasady wynika obowiązek zapewnienia skuteczności ustawodawstwa wspólnotowego, które obejmuje zarówno obowiązek wydania aktów prawa wewnętrznego wdrażających dyrektywy, jak i ewentualnie wydania odpowiednich aktów prawnych realizujących rozporządzenia wspólnotowe, jeżeli okazałoby się, że jest to konieczne dla prawidłowego stosowania rozporządzeń. Ponadto, zasada lojalności wskazuje, że konieczność interpretacji obowiązującego prawa krajowego istnieje w świetle tekstu i celów dyrektywy, po to, aby osiągnąć wyznaczony przez dyrektywę rezultat ${ }^{3}$.

Zob. wyrok z dnia 16 grudnia 1993 r. w sprawie Wagner Miret v. Fondo de garantia salarial (C-334/92), Zb. Orz. 1993, s. I-6912, pkt 20-22.

Takie tezy zostały wyrażone w wyroku TS z 5 października 2004 r. w sprawie Pfeiffer i inni v. Deutsches Rotes Kreuz, Kreisverband Walds (C-397/01-403/01), w którym stwierdzono, że „stosując prawo krajowe, a zwłaszcza przepisy uregulowania przyjętego specjalnie w celu wprowadzenia wymagań dyrektywy, sąd krajowy jest zobowiązany interpretować prawo krajowe w najszerszym możliwym zakresie w świetle brzmienia i celu danej dyrektywy, aby osiągnąć rezultat przez nią przewidziany” (par. 113). Podniesiono także, że „wymóg dokonywania wykładni zgodnej prawa krajowego jest związany z systemem Traktatu, gdyż zezwala sądowi krajowemu na zapewnienie, w ramach jego właściwości, pełnej skuteczności prawa wspólnotowego, gdy ten rozpatruje spór przed nim zawisły” (par. 114). I wreszcie zaznaczono, że „O ile zasada dokonywania wykładni zgodnej prawa krajowego dotyczy głównie przepisów krajowych przyjętych w celu transponowania danej dyrektywy, to nie ogranicza się ona jednakże do wykładni tych przepisów, ale sąd krajowy powinien brać pod uwagę całość norm prawa krajowego dla oceny tego, w jaki sposób mogą być stosowane, aby nie osiągnąć rezultatu sprzecznego z celem dyrektywy" (par. 115). 
Do podobnych wniosków doszedł Trybunał Sprawiedliwości w wyroku (C-334/92 Wagner-Miret), w którym wyraźnie stwierdził, że sąd krajowy, interpretując przepisy prawa krajowego jest obowiązany dokonywać wykładni tych przepisów - tak dalece, jak jest to możliwe - w świetle brzmienia i celu dyrektywy, aby osiągnąć wynik odpowiadający jej celowi i treści ${ }^{4}$. Tylko dla porządku wypada dodać, że zasada proeuropejskiej wykładni prawa krajowego dotyczyć powinna stosowania przez ustawodawcę, którego zadaniem jest odzwierciedlenie zobowiązania wiążącego państwo w prawie krajowym. W tym orzeczeniu wskazano także zasadę prowspólnotowej wykładni prawa krajowego, która powinna znaleźć zastosowanie w sytuacji domniemanej zgodności uprzednio obowiązującego prawa krajowego z uchwaloną dyrektywą. Jednocześnie czyniąc uwagi na temat wykładni prawa krajowego w kontekście prawa unijnego nie można zapominać i tego, że sąd krajowy ma obowiązek prounijnej wykładni prawa krajowego, zarówno wydanego przed, jak i po wprowadzeniu przepisów unijnych, która będzie w możliwie dużym stopniu zgodna z brzmieniem i celem dyrektywy, aby w ten sposób zapewnić realizację celu założonego przez dyrektywę ${ }^{5}$.

Konieczność zgodnej wykładni dotyczy wszystkich norm krajowych z punktu widzenia prawa unijnego, zarówno pierwotnego, jak i wtórnego. Odnosi się to do wszystkich przepisów krajowych, zarówno wydanych przed wejściem w życie danego aktu unijnego, jak i po nim, a także obejmuje obowiązek interpretacji przepisów prawa wewnętrznego w sposób zapewniający, na ile to tylko możliwe, realizację postanowień i celów aktu prawa europejskiego, ustalonych w świetle całego prawa unijnego i orzecznictwa sądów unijnych. Można więc przyjąć, że zasada dokonywania wykładni zgodnej z prawem krajowym dotyczy głównie przepisów krajowych przyjętych w celu transponowania danej dyrektywy. Nie ogranicza się ona jednak do wykładni tych przepisów, ale sąd krajowy powinien brać pod uwagę całość norm prawa krajowego dla oceny tego, w jaki sposób mogą być stosowane, aby nie osiągnąć rezultatu sprzecznego z celem dyrektywy ${ }^{6}$.

Trzeba również zaakcentować to, że każdorazowa wykładnia związana jest ze stosowaniem prawa krajowego, zwłaszcza wydanego w celu wdrożenia dyrektyw. Trybunał wskazał także, że można wyznaczyć granice wykładni zgodnej. Granice te wyznaczane są przez zasady ogólne prawa, szczególnie przez zasadę bezpieczeń-

4 Por. wyrok TS z dnia 16 grudnia 1993 r. w sprawie Wagner Miret v. Fondo de garantia salarial..., op. cit., pkt 22-23.

5 Jak bowiem stwierdził TS w wyroku z 13 listopada 1990 r. w sprawie C-106/89 Marleasing v La Comercial Internacional de Alimentación (Zb. Orz. 1990, l-4135, pkt 8), wynikające z dyrektywy zobowiązanie państwa członkowskiego do osiągnięcia rezultatu przewidzianego przez dyrektywę oraz ich obowiązek na mocy art. 5 Traktatu do podjęcia wszelkich właściwych środków ogólnych lub szczególnych w celu zapewnienia wykonania tego zobowiązania jest wiążące dla wszystkich organów państw członkowskich, włączając sądy w ramach ich kompetencji. Wynika z tego, że stosując prawo krajowe, niezależnie czy dane przepisy zostały przyjęte przed czy po dyrektywie, sąd krajowy wezwany do przeprowadzenia ich wykładni zobowiązany jest zrobić to, w największym możliwym stopniu, w świetle treści i celu dyrektywy, dla osiągnięcia jej rezultatu i przez to uzyskania zgodności z art. 189 akapit trzeci Traktat; A. Sakowicz, The principle of conforming interpretation..., op. cit., s. 85.

$6 \quad$ Zob. wyrok TS z dnia 25 lutego 1999 r. w sprawie Carbonari i in. (C-131/97), Zb. Orz. 1999 r., s. I-1103, pkt 50. 
stwa obrotu prawnego i zasadę lex retro non agit ${ }^{7}$. Ponadto, granicę zastosowania tej wykładni stanowi litera prawa danego państwa członkowskiego. Wszakże niedopuszczalna jest wykładnia contra legem, pomijająca brzmienie litery prawa krajowego. W tym względzie należy przypomnieć, że na mocy art. 288 akapit trzeci TFUE prawnie wiążący charakter dyrektywy, na którym opiera się możliwość powołania się na nią, istnieje wyłącznie w stosunku do „każdego państwa członkowskiego, do którego jest ona skierowana". Stąd też, zgodnie z utrwalonym orzecznictwem, sama dyrektywa nie może tworzyć obowiązków dla jednostki, a zatem nie można się na nią samą w sobie powoływać wobec takiej osoby przed sądem krajowym ${ }^{8}$.

Do chwili wejścia w życie Traktatu o UE, kwestia wykorzystywania wykładni przyjaznej prawu unijnemu w obszarze prawa karnego nie istniała. Dopiero wraz z powstaniem Unii Europejskiej i utworzeniem III filaru (współpraca policyjna i sądowa w sprawach karnych) postawiono pytania co do możliwości stosowania tej wykładni przy interpretacji przepisów krajowych prawa karnego implementujących decyzje ramowe. Prowadziło to jednak do wielu problemów, zwłaszcza że specyfika współpracy w sprawach karnych w UE zawsze rodziła wiele wątpliwości ${ }^{9}$. W szczególności podnoszono międzyrządowy charakter współpracy w tym obszarze. Wskazywano także na brak obowiązywania w III filarze zasady lojalności. Tylko nielicznie $w$ tej kwestii mieli odmienne zdanie. W literaturze brak było zgodności w tej kwestii ${ }^{10}$. Dopiero to orzeczenie TS z 16 czerwca 2005 roku w sprawie C-105/03 (sprawa Pupino) przyniosło jednoznaczne rozstrzygnięcie. Stwierdzono w nim, że ,artykuł 1 akapity drugi i trzeci Traktatu o UE stanowi, że traktat ten wyznacza nowy etap w procesie tworzenia coraz ściślejszego związku między narodami Europy, zaś zadaniem Unii, której podstawę stanowią Wspólnoty Europejskie, uzupełnione politykami i formami współpracy przewidzianymi tym traktatem, jest kształtowanie w sposób spójny i solidarny stosunków między państwami członkowskimi oraz między ich narodami. Z trudem przyszłoby Unii wypełnianie jej misji, gdyby zasada lojalnej współpracy, która zakłada między innymi, iż państwa członkowskie będą podejmować wszelkie właściwe środki ogólne lub szczególne celem zapewnienia wypełniania ich zobowiązań wynikających z Traktatu o UE, nie obowiązywała również w ramach współpracy policyjnej i sądowej w sprawach karnych, która zresztą w całości opiera się na współpracy między państwami członkowskimi a instytucjami ${ }^{11}$.

Zob. M. Koszowski, Granice prounijnej wykładni prawa krajowego, „Radca Prawny” 2012, nr 130, dodatek naukowy, s. 15D-20D. wyrok TS z dnia 14 lipca 1994 r. w sprawie Faccini Dori (C- C-91/92), Rec. s. I-3325, pkt 20 
Czyniąc dalsze rozważania TS wskazał, iż ,zasada wykładni zgodnej obowiązuje również w przypadku decyzji ramowych przyjętych na podstawie tytułu VI Traktatu o Unii Europejskiej. Aby osiągnąć rezultat zamierzony przez decyzję ramową i przez to zastosować się do art. 34 ust. 2 lit. b) UE, dokonujący wykładni sąd odsyłający, stosując prawo krajowe, ma obowiązek dokonać wykładni tego prawa, na ile to tylko możliwe, w świetle brzmienia i celów tej decyzji ramowej" ${ }^{2}$. Ostatnia część przytoczonego zdania wskazuje na to, że przy wykładni prawa krajowego należy odnieść się nie tylko do aktu prawa wtórnego (decyzji ramowej), ale także do postanowień prawa pierwotnego, czyli w tym wypadku do Traktatu o Unii Europejskiej. Łatwo przecież zauważyć, że podstawowym przecież celem aktów prawa wtórnego jest urzeczywistnienie zapisów traktatowych będących podstawą prawną ich wydania. W nowszym orzeczeniu TS podkreślił, że „obowiązek dokonywania wykładni prawa krajowego zgodnej z prawem unijnym jest bowiem nierozerwalnie związany z systemem TFUE, gdyż zezwala sądom krajowym na zapewnienie, w ramach ich właściwości, pełnej skuteczności prawa Unii przy rozpoznawaniu zawisłych przed nimi sporów"13.

Równocześnie TS w sprawie Pupino dodał, że spoczywający na sądzie krajowym obowiązek odniesienia się do decyzji ramowej przy dokonywaniu wykładni krajowego prawa karnego podlega ograniczeniom wynikającym z ogólnych zasad prawa, w tym w szczególności z zasady pewności prawa i niedziałania prawa wstecz. Obie te zasady - jak wyraził TS - stoją na przeszkodzie m.in. temu, aby na podstawie decyzji ramowej i niezależnie od ustawy wprowadzającej ją w życie rzeczony obowiązek mógł doprowadzić do ustalenia bądź zaostrzenia odpowiedzialności karnej osób naruszających przepisy prawa karnego ${ }^{14}$. To ostatnie ograniczenie wyraźnie odnosi się do sytuacji, kiedy to poprzez zgodną wykładnię kreuje się lub zaostrza odpowiedzialność w sferze prawa karnego materialnego, zwłaszcza poprzez tworzenie niejako per analogiam nowego typu przestępstwa ${ }^{15}$.

Pewną próbę zdefiniowania granic wykładni przepisów prawa karnego materialnego przy uwzględnieniu dyrektywy wykładni przyjaznej prawu unijnemu podjął TS w sprawie Pupino. W tym judykacie określono granice rzeczonej wykładni stwierdzając, iż spoczywający na sądzie krajowym obowiązek uwzględnienia treści decyzji ramowej (czy też obecnie dyrektywy) przy dokonywaniu wykładni odpowiednich przepisów prawa krajowego przestaje obowiązywać w chwili, gdy prawo krajowe nie może być zastosowane w sposób, który doprowadziłby do rezultatu zgodnego z celem wytyczonym przez tę decyzję ramową. Innymi słowy, ,zasada

12 Wyrok TS z 16 czerwca 2005 r. w sprawie Marii Pupino (C-105/03), Zb. Orze. 2005 r., s. I-5285, par. 43.

13 Zob. wyrok TS z 5 września 2012 r. w sprawie Joao Pedro Lopes Da Silva Jorge (C-42/11), pkt 54; wyrok TS z 24 stycznia 2012 r. w sprawie Dominguez (C-282/10) dotychczas nieopublikowany w Zbiorze, pkt 24.

14 Zob. Wyrok TS z 3 maja 2005 r. w sprawach połączonych Berlusconi i in. C-387/02, C-391/02 i C-403/02, Zb. Orz. ECR I-0000, par. 74; wyrok TS z 8 października 1987 r. w sprawie 80/86 Kolpinghuis Nijmegen (C-80/86), Zb. Orz. 1987, s. I-3969, par. 13.

A. Sakowicz, The principle of conforming interpretation..., op. cit., s. 88-89. 
wykładni zgodnej nie może stanowić podstawy do dokonywania wykładni prawa krajowego contra legem. Zasada ta wymaga jednak, aby w odpowiednim przypadku sąd krajowy wziął pod uwagę całokształt prawa krajowego celem dokonania oceny, w jakim stopniu prawo to może zostać zastosowane w taki sposób, który nie prowadziłby do rezultatu sprzecznego z celem wytyczonym przez decyzję ramową"16.

Orzeczenie w sprawie Pupino stało się kamieniem milowym w ewolucji prounijnej wykładni przepisów prawa karnego. Pokazuje ono, że stosowanie prawa karnego unijnego w sprawach karnych nie może stanowić automatycznie i w sposób wiążący podstawy modyfikacji nadrzędnych w hierarchii systemu prawa norm konstytucyjnych. Przyjęcie odmiennego stanowiska będzie mogło oznaczać, że uwzględnianie powyższego obowiązku w procesie wykładni krajowego prawa karnego może prowadzić do pogorszenia sytuacji prawnej jednostki oraz rodzić wątpliwość z perspektywy regulacji konstytucyjnych ${ }^{17}$. W konsekwencji nie zawsze będzie możliwa interpretacja prawa krajowego w zgodzie z ,europejskim” wzorcem wykładniczym oraz postulatem czynienia tej wykładnia „tak dalece, jak jest to możliwe”.

Specyfika regulacji prawa karnego, w szczególnością liczna rzesza gwarancji służących ochronie praw i wolności związanych z odpowiedzialnością karną oraz drogą procesową prowadzącą do materializacji owej odpowiedzialności, rodzi problemy ze stosowaniem wykładni prounijnej. Zostało to wyraźnie uwidocznione na przykładzie implementacji decyzji ramowej w sprawie europejskiego nakazu aresztowania oraz wykładni tej części przepisów kodeksu postępowania karnego, które stały się miejscem docelowym implementowanego tego instrumentu współpracy. Doświadczenia związane z tym instrumentem współpracy uwidoczniły szereg problemów, w tym także sprzężenia między wykładnią prounijną a nadrzędnością norm konstytucyjnych, które w ostateczności zakończyły się modyfikacją ustawy zasadniczej przez prawodawcę. Pozostawiając na uboczu rozważań problematykę związaną $\mathrm{z}$ europejskim nakazem aresztowania, stwierdzić jedynie należy, że prawo unijne stanowi niezależne źródło prawa, które nie może być uchylone przez przepisy prawa krajowego i to niezależnie od ich rangi. Nie jest przeto właściwym odwoływanie się do zasad i koncepcji prawa krajowego w celu oceny ważności środków przyjętych przez instytucje UE, ponieważ rodziłoby to negatywny wpływ na jednolitość i skuteczność prawa unijnego.

Nie jest również zasadnym tworzenie z konstytucyjnych norm o charakterze gwarancyjnym „forpoczty” obrony ich nadrzędności wobec norm zawartych w przepisach prawa unijnego z zakresu prawa karnego. Wszak nie trudno zauważyć, że poszanowanie praw podstawowych stanowi część prawa UE, jako zasady ogólne

16 17
Wyrok TS z 16 czerwca 2005 roku w sprawie Marii Pupino (C-105/03), Zb. Orze. 2005 r., s. I-5285, pkt 47.

Zob. P. Kardas, Rola i znaczenie wykładni prowspólnotowej..., op. cit., s. 23-27; M. Królikowski, Wokół problemów z zasadą nullum poena sine lege przy dostosowaniu kary orzeczonej w innym państwie członkowskim Unii Europejskiej; CzPKiNP 2009, nr 2, s. 33-54; P. Wiliński: Zasada nullum poena sine lege a wykonanie kary wobec osoby przekazanej w trybie ENA, CzPKiNP 2009, nr 2, s. 55-70; A. Sakowicz, Zasada ne bis in idem w prawie karnym, Białystok 2011, s. 20 i n. 
prawa (art. 6 ust. 3 TUE), w związku z czym ich ochrona musi być gwarantowana w ramach struktury i celów UE. Wydaje się, że ewentualna modyfikacja reguł konstytucyjnych powinna następować dopiero wówczas, gdy przeprowadzony proces dekodowania normy konstytucyjnej nie pozwala na uwzględnienie normy unijnej w sposób jednoznaczny. Aby stwierdzić istnienie takiego faktu, koniecznym jest podjęcie trudu interpretacyjnego, który powinien obejmować wszystkie krajowe akty prawne bez względu na ich rangę ${ }^{18}$. Nie można przy tym zapominać o konieczności respektowania $\mathrm{w}$ trakcie przeprowadzenia procesu wykładni praw i wolności jednostki. Na taką potrzebę zwrócił uwagę TS w wyroku z dnia 9 października 2008 r. w sprawie C-404/07 György Katz przeciwko István Roland Sós ${ }^{19}$ twierdząc, że przepisy decyzji ramowej powinny być ,,interpretowane w taki sposób, aby znalazły poszanowanie prawa podstawowe, wśród których trzeba między innymi wymienić zapisane w art. 6 EKPC prawo do rzetelnego procesu sądowego”. Wprawdzie teza powyższa dotyczy jedynie przepisu art. 6 EKPCz, bez jakichkolwiek wątpliwości, powinna zostać rozciągnięta na inne prawa podstawowe określone nie tylko w EKPCz, lecz także w Karcie Praw Podstawowych. W konsekwencji należy przyjąć, że wśród ograniczeń wykładni przepisów prawa karnego materialnego przy uwzględnieniu dyrektywy wykładni przyjaznej prawu unijnemu mieszczą się także i te, które wyrażają gwarancję praw i wolności jednostki.

Godzi się przy tym podkreślić, że sąd krajowy przystępując do wykładni, w pierwszej kolejności obowiązany jest zrekonstruować wzorzec interpretacyjny, który będzie stanowił przedmiot odniesienia w procesie dekodowania normy zawartej w przepisie prawa krajowego ${ }^{20}$. W tym względzie organ krajowy musi wniknąć w treść przepisów prawa unijnego i dokonać ich wykładni uwzględniającej nie li tylko jego literę, lecz także kontekst, system, funkcję i cel, któremu służy ${ }^{21}$. Konieczne jest nadto właściwe odczytanie prawa pochodnego w związku z prawem pierwotnym. Poza tym, w zakresie dyrektyw trzeba rozważyć, czy zawarty jest w nich standard minimalny czy może maksymalny. Nie można też zapomnieć, że szczególne znaczenie w procesie owej rekonstrukcji ma preambuła danego aktu prawnego oraz orzecznictwo wypracowane przez Trybunał Sprawiedliwości na podstawie regulacji, która jest przedmiotem wykładni22. Już powyższe ogólne uwagi prowadzą do wniosku, że wykładania prawa unijnego, która ma charakter autonomiczny, bazuje na priorytecie dyrektyw systemowych oraz celowościowych ${ }^{23}$.

\footnotetext{
18 P. Kardas, Rola i znaczenie wykładni prowspólnotowej..., op. cit., s. 24-25.

19 Zb. Orz. 2008, s. I-7607, pkt 49; zob. też A. Sakowicz, The principle of conforming interpretation..., op. cit., s. 89.

20 K. Płeszka, „lus” i „lex” w prowspólnotowej wykładni prawa krajowego, (w:) M. Borucka-Arctowa (red.), Prawo, władza, społeczeństwo, polityka. Księga jubileuszowa Profesora Krzysztofa Pałeckiego, Kraków 2006, s. 102. C. Mik, Wykładnia..., op. cit., s. 130.

P. Kardas, Rola i znaczenie wykładni prowspólnotowej..., op. cit., s. 18.

Zob. szerzej D. Fiedorow, Wykładnia celowościowa prawa wspólnotowego w orzecznictwie sądów Unii Europejskiej, (w:) C. Mik (red.), Wykładnia prawa Unii Europejskiej, Toruń 2008, s. 59-85.
} 
Stanowisko to znajduje odzwierciedlenie w orzecznictwie TS, w którym wskazuje się, że wprawdzie wykładnia językowa jest traktowana jako punkt wyjścia wykładni przepisów prawa unijnego, to jednak rzadko zamyka proces interpretacji ${ }^{24}$. Jednak coraz częściej odmawia się pierwszeństwa wykładni językowej na rzecz wykładni systemowej, funkcjonalnej oraz teleologicznej ${ }^{25}$. Nie wynika to li tylko z liczby języków oficjalnych, lecz także z faktu, że UE wraz z całym systemem prawnym znajdują się w ewolucji, w związku z czym wiele pojęć nie ma ustalonego znaczenia. Stąd łatwo zauważyć, że za odrzuceniem pierwszeństwa tej wykładni językowej przemawia posługiwanie się pojęciami autonomicznymi, które wyrażają wypadkową różnorodnych interesów państw członkowskich oraz są rezultatem działania licznych organów prawotwórczych UE. W konsekwencji ciężar wykładni zgodnej został przeniesiony na dyrektywy wykładni systemowej oraz celowościowej. Bez wątpienia wynika to z potrzeby osiągnięcia maksymalnego rezultatu obowiązujących regulacji z uwagi na istnienie odmienności systemów prawnych państw członkowskich, czy też usuwania niezgodności (konfliktu) pomiędzy normami krajowymi a normami unijnymi ${ }^{26}$.

Powracając do rozważań nad fazami wykładni zgodnej z prawem UE należy zauważyć, że kolejnym krokiem jest podjęcie dekodowania normy z przepisów prawa krajowego w oparciu o wewnętrzne reguły interpretacyjne $\mathrm{z}$ jednoczesnym obowiązkiem wykładni zgodnej. Wynik tego procesu powinien zostać skonfrontowany z wzorcem interpretacyjnym, co nie zawsze będzie łączyło się z pożądanym rezultatem. I tak, jeżeli w następstwie dyrektyw językowych zostanie osiągnięty jednoznaczny rezultat procesu interpretacji, pozostający w sprzeczności z normą unijną, wykładnia prounijna nie może stać się wykładnią contra legem, ponieważ tylko ustawodawca krajowy jest uprawniony do zmiany prawa. Uwaga ta dotyczy zarówno normy konstytucyjnej, jak i normy wyrażonej w ustawie zwykłej. Wskazanie powyższe oznacza, że obowiązek wykładni zgodnej nie może prowadzić do zaprzeczenia prawa krajowego bądź ,do rezultatu dokładnie odwrotnego do tego, jaki zakładał ustawodawca (krajowy - A.S.)"27. Na tym tle, w literaturze prawa europejskiego podkreśla się, że zakazanym jest przeprowadzenie wykładni zgodnej w sposób sprzeczny z wyraźnymi postanowieniami aktu prawa krajowego bądź ,wbrew

24 Por. C. Gulman, Methods of interpretation of the European Court of Justice, „Scandinavian Studies in Law” 1980, vol. 24, s. 198-199.

25 A. Kalisz, Wykładnia i stosowanie prawa wspólnotowego, Warszawa 2007, s. 156 i podana tam literatura; M. Górka, Zasada stosowania języków państw członkowskich w systemie prawnym Unii Europejskiej, „Radca Prawny" 2004, nr 3, s. 23 in. 26 W literaturze występują także poglądy krytyczne, które postrzegają odstępstwo od wykładni językowej, jako „re-
kompensatę" deficytu demokracji w obrębie UE. Przykładowo M. Klatta podnosi, że nie ma żadnych podstaw do odmiennej oceny pozycji granicy językowej w stosunku do prawa wspólnotowego i prawa krajowego, M. Klatt, Theorie der Wortlautgrenze. Semantische Normativität in der juristischen Argumentation, Baden-Baden 2004, s. 26; zob. również A. Sakowicz, The principle of conforming interpretation..., op. cit., s. 89.

27 K. Kowalik-Bończyk, Prowspólnotowa wykładnia prawa polskiego, „Europejski Przegląd Sądowy” 2005, nr 3, s. 14 . 
oczywistej treści przepisu wewnętrznego"28. Dlatego też słusznym jest twierdzenie, że w ramach wykładni zgodnej, będącej odmianą dyrektywy celowościowej, organ krajowy może dokonywać li tylko wykładni uszczegóławiającej lub doprecyzowującej (tj. wykładni infra lub intra legem) albo wykładni uzupełniającej (wykładni praeter legem ${ }^{29}$. To, czy będzie zachodziła taka potrzeba, a jeżeli tak, to sposób w jaki nastąpi jej przeprowadzenie, będą zależały od sądu krajowego.

Dodać należy, że dla oceny tego, co stanowi wykładnię contra legem w konkretnym przypadku należy odnieść się do prawa krajowego oraz uznanych w prawie krajowym metod wykładni. Nie jest to kwestia oczywista, ponieważ można odnaleźć takie orzeczenia TS, w których sugeruje się, że sąd ,krajowy wezwany do przeprowadzenia ich wykładni zobowiązany jest zrobić to, w największym możliwym stopniu, w świetle treści i celu dyrektywy, dla osiągnięcia jej rezultatu" ${ }^{30}$. Takie stanowisko może być uznane za trafne jedynie w takiej sytuacji, w której norma prawa unijnego nadaje się do bezpośredniego stosowania. Wtenczas, jeżeli pomimo zastosowania wykładni zgodnej norma prawa krajowego pozostaje w sprzeczności z wspólnotowym wzorcem normatywnym, to sąd krajowy ma obowiązek odstąpić od stosowania normy krajowej i zastosować normę unijną, o ile nadaje się ona do bezpośredniego zastosowania. Aby tak się stało, przepis unijny musi być jasny, bezwarunkowy i uniezależniony od konieczności implementacji przez organy krajowe lub unijne. Dopiero spełnienie powyższych kryteriów pozwala powołać się na określoną normę przed krajowymi organami stosowania prawa.

Gwoli ścisłości przypomnieć należy, że w prawie unijnym bezpośrednią skuteczność (direct effect) posiadają przepisy prawa pierwotnego. Poza nimi, zgodnie $\mathrm{z}$ art. 288 tiret drugi TFUE, rozporządzenia wiążą w całości i są bezpośrednio stosowane we wszystkich państwach członkowskich, zatem normy zawarte w rozporządzeniach ze swej natury wywołują skutki bezpośrednie. Inaczej przedstawia się sytuacja w przypadku dyrektyw, które wyrażają pośredni tryb regulacji za pośrednictwem prawa krajowego implementującego je do systemu prawnego państw członkowskich. Tylko w wyjątkowych sytuacjach dyrektywy mogą cechować się skutkiem bezpośrednim. Będzie miało to miejsce w sytuacji braku wdrożenia dyrektywy w wyznaczonym terminie lub jej nieprawidłowego wdrożenia. Przy czym, jak podkreśla się w orzecznictwie TS, nawet w tak szczególnych sytuacjach przepisy

28 K. Wójtowicz, Zasady stosowania prawa wspólnotowego w państwach członkowskich Unii Europejskiej, ,Zeszyty CEN" 2003, nr 8, s. 21.

29 C. Mik, Wykładnia zgodna prawa krajowego..., op. cit., s. 162.

30 Zob. Case C-106/89 Marleasing [1990] ECR I-4135, paragraph 8; zob. także wyrok TS z dnia 8 października 1987 r. w sprawie Kolpinghuis Nijmegen (C-80/86), Zb. Orz. 1987 r., s. 3969, pkt 13, wyrok TS z dnia 4 lipca 2006 r. w sprawie Adeneler i in. (C-212/04), Zb. Orz. 2006 r., s. I-6057, pkt 110 oraz wyrok TS z dnia 23 kwietnia 2009 r. w sprawie Angelida-ki i in. (C-378/07), Zb. Orz. 2009, s. I-3071, pkt 199; wyrok z dnia 16 czerwca 2005 r. w sprawie Pupino (C-105/03), Zb. Orz. 2005 r. s. I-5285, pkt 44 i 47. W literaturze patrz: S. Biernat, Wykładnia prawa krajowego zgodnie z prawem Wspólnot Europejskich, (w:) C. Mik (red.), Implementacja prawa integracji europejskiej..., op. cit., s. 134; K. Kowalik-Bańczyk: Prowspólnotowa wykładnia prawa..., op. cit., s. 9-18; M. Szpunar, Odpowiedzialność podmiotu prywatnego z tytułu naruszenia prawa wspólnotowego, Warszawa 2008, s. 170-173. 
dyrektywy nie mogą być źródłem obowiązków jednostki. Jest to następstwem tezy, że organy państwa nie mogą czerpać korzyści z faktu niewdrożenia lub nieprawidłowego wdrożenia dyrektywy ${ }^{31}$.

$\mathrm{Z}$ powyższego można wprowadzić pogląd, że każda norma unijna może być wzorcem dla interpretacji zgodnej, lecz w razie niemożności jej efektywnego zastosowania tylko niektóre $\mathrm{z}$ nich przyniosą pożądany rezultat w postaci skutku bezpośredniego. Posiadanie takiego waloru przez przepisy prawa unijnego nie może stanowić per se podstawy odpowiedzialności karnej lub jej zaostrzenia. Jak trafnie wskazał TS w wyroku w sprawie Berlusconi „w szczególnych okolicznościach, gdy organy państwa członkowskiego $\mathrm{w}$ stosunku do jednostki w ramach postępowania karnego powołują się na dyrektywę, nie może ona samoistnie skutkować, niezależnie od wewnętrznej ustawy państwa członkowskiego wydanej w celu jej wykonania, ustaleniem lub zaostrzeniem odpowiedzialności karnej osób, które naruszyły tę dyrektywę" ${ }^{32}$. Wypowiedź ta wpisuje się w dotychczasową linię orzeczniczą TS, że dyrektywa nie może samoistnie tworzyć po stronie jednostki obowiązków, i zatem nie może być samodzielnie powoływana wobec tej jednostki ${ }^{33}$.

Granice, jak dalece może sąd krajowy odejść od literalnego brzmienia przepisu na rzecz wykładni prounijnej, wynikają z treści owego przepisu prawa krajowego oraz uznanych w prawie krajowym metod wykładni. W sytuacji, gdy dyrektywy językowe nie prowadzą do odczytania jednoznacznej normy zakodowanej w przepisie prawa krajowego, należy uruchomić procedury interpretacyjne w oparciu o dyrektywy systemowe i funkcjonalne. Na tym etapie sąd krajowy jest obowiązany sprawdzić, czy treść normy przy którymś z możliwych znaczeń interpretowanego przepisu prawa krajowego nie znajduje się w konflikcie z normami prawa UE. W przypadku wystąpienia takiego konfliktu interpretator powinien odrzucić te znaczenia interpretowanego zwrotu, które do takiego konfliktu prowadzą.

Aby zapobiec naruszeniu prawa unijnego sąd krajowy powinien, w zawisłych przed nim sprawach, „,zynić wszystko co leży w zakresie jego właściwości”, biorąc pod uwagę całość norm prawa krajowego, aby zagwarantować skuteczność (effet utile $^{34}$ norm prawa UE. Oznacza to, że organ krajowy jest obowiązany - na podstawie zasady wykładni zgodnej - uwzględnić całość jego norm i interpretować je w najszerszym możliwym zakresie (także norm osadzonych w przepisach ustawy zasadniczej) w świetle brzmienia i celu danego aktu prawnego UE, aby osiągnąć rezultat przez nią przewidziany. Jak zauważa TS w sprawie Pfeiffer „w tym kon-

Por. B. Kurcz, Wspólnoty Europejskiej i ich implementacja do prawa krajowego, Kraków 2004, s. 204-223. Wyrok z 3 maja 2005 r. w połączonych sprawach C-387/02, C-391/02 i C-403/02 Postępowania karne przeciwko Silviemu Berlusconi, Sergiowi Adelchiemu, Marcellowi Dell'Utriemu i innym, Zb. Orz. 2005, s I-3565, pkt 74. W szczególności wyrok TS z dnia 5 października 2004 r. w sprawie Pfeiffer (C-397-403/01), Zb. Orz. 2004, s. I-8835, pkt 108 i powołane tam orzecznictwo.

Wyrok TS z dnia 16 lipca 2009 r. w sprawie Mono Car Styling SA, w likwidacji v. Dervis Odemis i in. (C-12/08), Zb. Orz. 2009, s. I-6653, pkt. 64. Patrz także C. Mik, Wykładnia zgodna..., op. cit., s. 161; M. Szpunar, Odpowiedzialność podmiotu prywatnego..., s. 172-174; S. Biernat, (w:) J. Barcz (red.), Prawo Unii Europejskiej..., s. I-291; zob. też A. Sakowicz, The principle of conforming interpretation..., op. cit., s. 95. 
tekście, jeśli prawo krajowe, stosując uznane przez nie metody wykładni, zezwala, w pewnych okolicznościach, na taką wykładnię przepisu krajowego porządku prawnego, że konflikt z inną normą prawa krajowego zostanie uniknięty lub na ograniczenie w tym celu zakresu danego przepisu poprzez stosowanie go tylko jeżeli jest zgodny z tą normą, sąd krajowy jest zobowiązany stosować te same metody w celu osiągnięcia rezultatu wytyczonego przez dyrektywę" 35 .

Nakreślone wyżej uwagi pozwalają twierdzić, że wymóg zgodnej wykładni nie może prowadzić do tego, że zostanie ,ustanowiona bądź zwiększona odpowiedzialność karna"36, ani prowadzić do naruszenia zasady pewności prawa i jego nieretroaktywności. Norma prawa krajowego, która odnosi się do prawa represyjnego, nie może w drodze wykładni prounijnej doprowadzić do ustalenia nowej podstawy odpowiedzialności karnej przełamując dyrektywy semantyczne. Wykładnia ta nie może również prowadzić do rozszerzenia zakresu zastosowania tej normy krajowej, ani też kreować innego skutku na niekorzyść osoby poddanej odpowiedzialności karnej ${ }^{37}$. Na przeszkodzie stoi bowiem zasada nullum crimen sine lege, która stanowi część ogólnych zasad prawa unijnego, będących podstawą tradycji konstytucyjnych wspólnych dla państw członkowskich i została wyrażona w różnych umowach międzynarodowych, w szczególności w art. 7 Europejskiej konwencji praw człowieka oraz art. 49 ust. 1 Karty Praw Podstawowych ${ }^{38}$.

Ponadto, sąd krajowy dokonujący wykładni zgodnej z prawem UE jest ograniczony przez ogólne zasady prawa, w tym zasadę pewności prawa, zasadę niedziałania prawa wstecz ${ }^{39}$. Stanowią one także odzwierciedlenie zarówno standardu konstytucyjnego, jak i kultury prawnej, przesądzającej o modelu odpowiedzialności karnej i systemie reguł gwarancyjnych w sferze praw i wolności jednostki.

35 Wyrok TS z 5 października 2004 r. w sprawie Pfeiffer (C-397-403/01), Zb. Orz. 2004, s. I-8835, pkt 116.

36 Por. wyrok TS z 26 lutego 1986 r. w sprawie Marshall (C-152/84), Zb. Orz. 1986, s. 723, pkt 48; wyrok TS z 8 października 1987 r. w sprawie Kolpinghuis Nijmegen (C-80/86), Zb. Orze. 1987, s. 3969.

37 Należy wskazać, że w wyroku TS stwierdził, że obowiązek sądu krajowego do interpretacji dyrektyw kończy się w momencie, gdy interpretacja prowadzi do nałożenia na jednostkę obowiązku wynikającego z dyrektywy, która nie została transponowana do prawa krajowego lub jeśli wykładnia prowadzi, na podstawie dyrektywy i przy braku regulacji przyjętej dla jej implementacji, do ustanowienia lub pogorszenia odpowiedzialności karnej osób działających sprzecznie z postanowieniami dyrektyw. Jak bowiem zauważył TS „w razie zaniechania przez państwo członkowskie pełnego wykonania dyrektywy w przepisanym terminie, (...) władza publiczna tego państwa członkowskiego nie może powołać się na przepis (...) dyrektywy przeciwko jednostce, bowiem z takiej możliwości mogą skorzystać jedynie jednostki i tylko w stosunku do państwa, do którego dyrektywa jest adresowana" zob. wyrok TS z 26 września 1996 r. w sprawie Arcaro (C-168/95), Zb. Orz. 1997, s. I-4705, pkt 44; P. Kardas, Rola i znaczenie wykładni..., s. 21; M. Szpunar, Odpowiedzialność podmiotu prywatnego..., s. 179-180.

38 Wyrok TS z 12 grudnia 1996 r. w sprawie Postępowanie karne przeciwko (w połączonych sprawach C-74/95 i C-129/95), Zb. Orz. 1996, s. I-6609, pkt 24-25; M. Wąsek-Wiaderek, (w:) A. Grzelak, M. Królikowski, A. Sakowicz (red.), Europejskie prawo karne..., op. cit., 287-288; H. Satzger, International and European Criminal Law, München 2012, s. 101.

39 Wyrok TS z dnia 3 maja 2007 r. w sprawie Advocaten voor de Wereld (C-303/05), Zb. Orz. TS 2007 r., s. I-3633, pkt 49. 


\section{THE CRUCIAL PROBLEMS OF CONFORMING INTERPRETATION OF NATIONAL LAW IN THE AREA OF CRIMINAL LAW}

This paper aims at presenting general remarks about the principle of conforming interpretation of national law in the area of criminal law. Through the syntactic and semantic analysis of the legal provisions originating from various branches of law, the paper is an attempt to answer the question of the interrelation between legal provisions established by different legislators and the rules of law reconstructed during the process of legal interpretation. The unique nature of criminal law, in particular the large number of guarantees intended to protect rights and freedoms connected with liability in criminal law and the conduct of the process leading to realization of such responsibility, is the source of problems with application of interpretation of national law conforming to European law. Among several possible interpretation of a criminal law, a court must prefer the one which best enforces European law. But, the principle of legality sets a limit. Thus, it appears that interpretation conforming to European laws cannot lead to an expansion of the scope of application of norms of national law pertaining to penal law or have other effects that are disadvantageous to the persons who face liability in criminal law.

Keywords: criminal law, EU law, legal interpretation, conforming interpretation, directive 